\title{
PERAN PENDIDIK DALAM PENERAPAN INTERNET SEHAT MENURUT ISLAM
}

\author{
Ahmad Saefulloh \\ ahmad.saifullah39@gmail.com \\ Prodi Pendidikan Agama Islam, STIT AD Jambi
}

\begin{abstract}
The purpose of this study is to find out the role of educators in applying healthy internet use according to Islam. This study used descriptive qualitative method with phenomenalogy analysis involving several family members. Data collection through snowball sampling technique to get saturated data. The results of this study that preventive steps that can be done by educators and parents so that students can implement healthy internet use according to Islam is by following the roles and duties of the Prophet Muhammad in educating, educating and parents also need to know the use of the internet and do some preventive tricks such as conducting assistance, carrying out the 1821 movement, and conducting educative supervision of children's internet use. So that children activities can be controlled well.
\end{abstract}

Keywords: Healthy; Internet; Islam

\begin{abstract}
Abstrak
Tujuan kajian ini untuk mengetahui peran pendidik dalam menerapkan penggunaan internet yang sehat menurut islam. Kajian ilmiah ini menggunakan metode deskriptif kualitatif dengan analisis fenomenalogy yang melibatkan beberapa anggota keluarga. Pengumpulan data melalui teknik snowball sampling sampai mendapatkan data jenuh. Hasil dari kajian ini bahwa langkah preventif yang dapat dilakukan pendidik dan orang tua agar anak didik dapat menerapkan penggunaan internet yang sehat menurut Islam adalah dengan cara mengikuti Peran dan tugas Rasulullah SAW dalam mendidik, pendidik dan orang tua juga perlu mengetahui penggunaan internet serta melakukan beberapa trik preventif seperti melakukan pendampingan, melakukan gerakan 1821, dan melakukan pengawasan edukatif terhadap penggunaan internet anak. Sehingga kegiatan anak dapat dikendalikan dengan baik sesuai dengan perintah Allah SWT dan Rasul-Nya.
\end{abstract}

Kata Kunci : internet; islam; sehat

\section{PENDAHULUAN}

Artikel ini beranjak dari bentuk kekhawatiran selaku tenaga pendidik yang melihat situs-situs bebas bergentayangan di dunia maya. Sayang kebebasan di dunia maya tersebut tidak terkendali bahkan di luar jangkauan, seolah kita dibawa dalam suasana "mencari tulang di antara daging" dalam arti kata susahnya membedakan mana saja situs yang aman untuk diakses. Tidak semuanya yang diperoleh dari situs tersebut adalah baik dan benar adanya. Oleh karena itu sikap yang baik adalah tetap selektif dalam memilih, sebab di dalam sana semuanya tumpah ruah, yang baik dan yang buruk, 
benar dan jahat, yang patut dan tidak patut, yang pantas dan tidak pantas menjadi satu dalam genggaman anda, seperti yang dilakukan oleh sebagian peneliti remaja Sekolah di Johor Bahru Malaysia terhadap 256 pelajar dari 3 sekolah bahwa tingkat pengguna internet lebih banyak di kalangan pelajar daripada non pelajar (Hassan \& Rashid, 2012).

Menurut tata bahasa internet berasal dari bahasa yunani "inter" yang berarti “antara”. Sementara itu menurut situs (Wikipedia, 2018) internet merupakan singkatan dari interconnection-networking yang merupakan sistem jaringan yang menghubungkan tiap-tiap komputer secara global di seluruh penjuru dunia. Koneksi yang menghubungkan masing masing komputer tersebut memiliki standar yang digunakan yang disebut Internet Protocol Suite disingkat TCP/IP. Komputer yang terhubung ke internet akan memiliki kemampuan melakukan pertukaran data dengan sangat cepat.

Jika di lihat dari segi zaman now - istilah kekinian untuk menyebut kondisi saat ini - pemanfaatan internet tidak lagi hanya sebatas perihal di atas, namun sudah jauh dari itu, keberadaan internet sudah berada digenggaman seluruh lapisan masyarakat dan tidak dibatasi oleh usia. Bahkan, di era zaman now ini seorang bayi pun sudah bisa menggunakan internet.

Seiring berjalannya waktu, internet mulai memberikan kontribusi tersendiri bagi kalangan tertentu. Ada yang memanfaatkannya sebagai ajang dakwah, iklan, promosi perusahaan maupun diri sendiri, sebagai sarana pengumpul kolega, pengganti buku pengetahuan, hingga menjadi sebuah kendaraan cyber yang memanjakan pengguna tertentu. Dari kegunaan-kegunaan tersebut, setidaknya banyak hal yang bermanfaat akan lahirnya akses internet ini, namun demikian juga tidak sedikit yang menjadikannya sebagai sarana tindak kejahatan kriminal dengan beragam motif yang digunakan, seperti adanya pemberitahuan selamat atas terpilihnya sebagai pemenang suatu undian yang sudah ditayangkan pada dini hari di salah satu televisi swasta. Ada juga yang bermotif sebagai pembeli yang berminat dengan produk jualan online reseller, yang kemudian terjadi perampasan, hingga informasi prostitusi dan perjudian. Semua layanan informasi tersebut merupakan tindakan kriminal yang di atur dalam Undang-undang ITE (Informasi dan Transaksi Elektronik) No. 11 Tahun 2008 disebutkan di dalam Bab VII pasal 27 ayat 1, 2, 3, dan 4 tentang larangan mengakses informasi yang melanggar kesusilaan, perjudian, pencemaran nama baik serta pengancaman dan pemerasan. 
Dalam pasal 28 ayat 1 dijelaskan larangan menyebarkan berita bohong yang menyesatkan sehingga mengakibatkan kerugian konsumen dalam transaksi elektronik. Pada ayat 2 disebutkan larangan menyebarkan informasi yang ditujukan untuk menimbulkan rasa kebencian atau permusuhan individu dan/atau kelompok masyarakat tertentu berdasarkan atas suku, agama, ras, dan antargolongan (SARA).

Peraturan tersebut merupakan salah satu rambu-rambu yang membatasi akses kebebasan setiap pengguna internet untuk mengakses informasi elektroniknya, sehingga pengguna tetap menggunakan kebebasan berekspresi tetap berada pada jalur koridor yang pantas. Larangan yang tertuang dalam undang-undang ITE juga diterbitkan sebagai bukti adanya dampak negatif yang timbul jika tidak segera dibatasi.

Dalam BAB II tentang asas dan tujuan dari adanya informasi elektronik, sebagaimana yang tercantum dalam pasal 4 bahwa tujuan pemanfaatan teknologi informasi dan transaksi elektronik di antaranya; (1) Mencerdaskan kehidupan bangsa sebagai bagian dari masyarakat informasi dunia; (2) Mengembangkan perdagangan dan perekonomian nasional dalam rangka meningkatkan kesejahteraan masyarakat; (3) Meningkatkan efektivitas dan efisiensi pelayanan publik; (4) Membuka kesempatan seluas-luasnya kepada setiap Orang untuk memajukan pemikiran dan kemampuan di bidang penggunaan dan pemanfaatan Teknologi Informasi seoptimal mungkin dan bertanggung jawab; (5) Memberikan rasa aman, keadilan, dan kepastian hukum bagi pengguna dan penyelenggara Teknologi Informasi.

Pasal tersebut dibuat dalam rangka memberikan kebebasan seluas-luasnya untuk berkarya, bisa dalam hal berdakwah, mendidik, serta menghubungkan jalinan silaturrahmi antara sesama pengguna elektronik melalui akses jaringan internetnya. Di samping itu, pasal tersebut hadir setelah adanya out off control para pengguna yang bersifat amoral dan disability value sehingga menjadi pemicu munculnya persepsi negatif terhadap penggunaan internet. Secara spesifik manfaat penggunaan internet seperti berikut; (1) Internet sebagai media komunikasi, merupakan fungsi internet yang paling banyak digunakan di mana setiap pengguna internet dapat berkomunikasi dengan pengguna lainnya dari seluruh dunia; (2) Media pertukaran data, dengan menggunakan email, newsgroup, ftp dan www (world wide web / jaringan situs-situs web) para pengguna internet di seluruh dunia dapat saling bertukar informasi dengan cepat dan murah; (3) Media untuk mencari informasi atau data, perkembangan internet yang pesat, 
menjadikan internet sebagai salah satu sumber informasi yang penting dan akurat; (4) Kemudahan bertransaksi dan berbisnis dalam bidang perdagangan sehingga tidak perlu pergi menuju ke tempat penawaran/penjualan

Dampak negatif yang sudah jelas muncul adalah sebagaimana yang tertuang dalam pasal 27 ayat 1, 2, 3 dan 4 serta ditunjang dengan pasal 28. Bahwa di dalam pasal tersebut dikhawatirkan akan berlanjutnya tindakan kriminal melalui cyber of link baik dalam bentuk kebohongan publik, pencemaran nama baik, kekerasan, penipuan, hingga pornografi dan prostitusi online. Kehadiran produk jaringan internet di era saat ini sudah menjadi ketergantungan serious yang menyatu dengan kebiasaan, terutama di kalangan anak-anak dan remaja.

Sikap ketergantungan pada mereka sudah tidak bisa lagi dilepaskan dari kehidupan seolah-olah pecandu rokok yang tidak bisa berhenti. Adanya tindak kriminalitas bersumber dari tayangan internet yang ditonton oleh anak, baik melalui Watshapp, facebook, Instagram, maupun medsos lain yang dapat menghimpun gambar maupun video lainnya. Selain itu, hadirnya perangkat android yang menyatu di dalam handphone semakin memudahkan pengguna dalam mengakses situs-situs terlarang. Meskipun sudah sekian kali pihak pemerintah yang bekerja sama dengan pemangku agama dalam memberantas akses situs terlarang tersebut, namun masih tetap juga bermunculan situs-situs baru yang tidak terkontrol. Selain situs dan website juga terdapat aplikasi-aplikasi chat yang dampak postif dan negatifnya dikendalikan oleh pengguna. Seperti com frog, mono live, nono live dan aplikasi chat lainnya yang dapat melakukan siaran langsung dan mentransfer bentuk kondisi komunikator. Hal ini menimbulkan sebuah kekhawatiran bagi para orang tua dan pendidik dalam membina akhlak putra-putri mereka (Suyatno, 2011).

Internet adalah sebuah produk teknologi. Sebuah produk tentu memberikan dampak negatif dan positif. Dampak negatif atau positif dapat dirasakan oleh semua kalangan, termasuk pelajar. Dampak positif atau negatif dari internet bagi pelajar tentu saja ditimbulkan dari cara penggunaan internet itu sendiri. Penggunaan internet sebagai media penghubung serba cepat memang sudah tidak mudah dipisahkan dari kehidupan kita. Segala macam persoalan komunikasi dapat diselesaikan dengan internet. Dampak positif dan negatif internet bagi pelajar tentu saja tidak muncul bersamaan. Seharusnya dampak positif lebih mendominasi, jika cara penggunaan internet itu benar. Dampak 
positif dan negatif bagi pelajar sifatnya tidak mutlak. Penilaiannya terletak pada apa yang dirasakan secara personal (Widiastuti \& Elshap, 2015).

Di antara dampak negatif internet bagi pelajar terbagi menjadi tiga kategori. Pertama; Dampak asosial. Dampak negatif yang paling umum dialami oleh pelajar adalah kecenderungan untuk lebih nyaman berkomunikasi melalui internet daripada secara langsung. Ia akan merasa lebih memiliki kedekatan dengan obyek komunikasi melalui internet, daripada berkomunikasi langsung. Hal ini akan memunculkan rasa asosial yang membuat seorang pelajar mengisolasi diri. Memang ada dampak positif dari kedekatan pelajar dengan internet, yakni dapat mengenal seluk beluk internet dengan baik, namun akan merugikan jika pada akhirnya seorang pelajar merasa lebih nyaman berhubungan dengan benda mati daripada berhubungan dengan manusia. Rasa emosi menjadi kurang tajam dan mengakibatkannya tidak peka terhadap lingkungan.

Kedua; Mengganggu kesehatan (R, Mudjiran, \& Syukur, 2012). Dampak negatif internet bagi pelajar adalah kesehatan mata, terlalu sering melihat gadget menyebabkan gangguan saraf pada retina dan menimbulkan rabun. Terlalu sering berada di depan layar dengan terkoneksi pada internet menyebabkan organ tubuh mengalami kelelahan dan disfungsi organ tubuh tertentu. Selain itu ada kemungkinan terjadinya kriminalitas yang merupakan dampak kemudahan internet. Pada awalnya hanya pencurian identitas, lalu penjualan barang palsu yang bermaksud menipu lalu merembet pada motif kejahatan lain seperti perampokan. Hal ini bisa terjadi setelah sebelumnya mengetahui alamat korban dari internet atau jejaring sosial.

Ketiga; Pornografi, selain itu ada yang paling dekat dengan internet dan sangat negatif, yakni pornografi. Publikasi pornografi melalui jaringan internet, bukan hal yang aneh dan baru. Kecanggihan teknologi informasi dan komunikasi merupakan instrumen yang menunjang penyebaran pornografi (Rumtianing \& Hanifah, 2013). Pornografi memang hal yang sangat rentan terjadi di internet. Dampak negatif yang ditimbulkannya pun dapat dilihat secara langsung dalam tempo yang tidak terlalu lama. Bagi kalangan remaja yang masih labil, mereka akan menganggap aksi pornografi yang dilihatnya melalui internet adalaih hal yang wajar. Itulah penyebab banyaknya penyimpangan perilaku seksual para remaja dewasa ini, mengingat mereka mendapatkan pendidikan seks dari sumber yang menyesatkan (Hanifah, 2013). 
Banyak penelitian yang dilakukan berkaitan dengan penggunaan internet (Halim, 2015; Hassan \& Rashid, 2012; Ihsan, 2016; Iman, Katni, \& Kurniawan, 2014; Ismail, 2014; Kurniali, 2011; Satya, Rosidi, \& Arief, 2012; Setiawan, 2011; Situmorang, 2012; Sudiran, 2015; Widiastuti \& Elshap, 2015; Winarso, Syahril, Aryanto, Arribe, \& Diansyah, 2017; Wiranto, 2014). Keberadaan internet bagaikan buah simalakama yang sangat bergantung dengan penggunanya (user). Belum lagi pembatasan di dunia maya masih belum menyentuh semua masalah yang ada, namun sisi baiknya adalah melatih kedewasaan berfikir dan pengendalian diri. Salah satu dari produk yang muncul dalam ranah internet adalah media masa, yang sering dikenal dengan medsos. Melalui medsos banyak hal dapat terjadi, medsos dapat mempersatukan orang banyak, dapat mengumpulkan masa dalam jumlah besar dalam hitungan jam saja, juga dapat menjadi sarana jitu untuk menyebarkan provokasi untuk memecah belah keutuhan suatu lembaga, organisasi hingga keluarga (Supratman, 2015). Salah satu penyebab terjadinya perpecahan, perseteruan, maupun perceraian di antara individu adalah akibat komunikasi verbal melalui media masa. Maka, dari hal tersebut perlu adanya klarivikasi media sosial agar tidak terperangkap dalam hoax.

Sulit memang untuk membedakan hoax dan fakta (Budiman, 2017). Berita bohong (hoax) di media sosial tumbuh subur pada kondisi masyarakat yang menginginkan kemudahan dalam melakukan interaksi komunikasi melalui media sosial. Berita bohong memang diproduksi tidak dengan memperhatikan kaidah penulisan berita yang menjadi panduan dalam penulisan berita pada pelaksanaan tugas jurnalistik media. Berita bohong melalui media sosial tidak boleh dibiarkan, karena kemampuan media sosial yang dimanfaatkan untuk menyajikan berita yang tidak dilandasi fakta peristiwa cenderung menimbulkan ketidakpastian informasi, mampu menciptakan opini publik yang tidak berlandaskan fakta berita, dan menyebabkan keresahan dalam masyarakat.

Banyak orang sudah menjadi korban hoax karena terlampau taqlid mempercayai, banyak orang terkena hasut dan fitnah yang menyebabkan perpecahan dan diskomunikasi, yang ternyata penyebabnya adalah kurangnya ketelitian dan kejelian berfikir dalam menangkap sebuah informasi baru. Namun juga tidak sedikit yang menjadikan medsos sebagai sarana dakwah untuk menyebarkan kebaikan, sarana untuk mengajak ber-fastabiqul khairat, sarana untuk menjalin silaturrahmi jarak jauh, bahkan akhir-akhir ini medsos juga dijadikan sebagai sarana e-learning melalui system tutorial 
(Yudhianto-detikInet, 2017). Hal ini berdasarkan kajian survey yang dilakukan oleh laporan Tetra Pak Index 2017 yang belum lama diluncurkan, mencatatkan ada sekitar 132 juta pengguna internet di Indonesia. Sementara hampir setengahnya adalah penggila media sosial, atau berkisar di angka 40\%. Angka ini meningkat lumayan dibanding tahun lalu, di 2016 kenaikan penguna internet di Indonesia berkisar 51\% atau sekitar 45 juta pengguna, diikuti dengan pertumbuhan sebesar 34\% pengguna aktif media social. Salah satu manfaat medsos bagi seorang guru di mana mereka dapat memberikan panduan modul dan pada tahap tertentu harus mencapai target melalui system pelaporan rutin untuk melangkah ke tingkat selanjutnya. Salah satu contoh adalah program ODOJ (One Day One Juz), yaitu bentuk pembelajaran secara tutorial yang mengharuskan anggota groupnya melaporkan sucara jujur jika sudah membaca al-Quran sebanyak satu juz dalam satu hari tersebut. Contoh lain pemanfaatan medsos sebagai ajang tempat konsultasi secara e-learning adalah tutorial pembelajaran bahasa arab dasar, tutorial bahasa inggris dasar, hingga tutorial membuat aplikasi pemograman.

Beberapa bentuk pemanfaatan medsos di atas, dalam hemat penulis merupakan bentuk percepatan pembelajaran dan efisiensi material. Hanya menggunakan kuota data untuk mengakses internet dengan biaya yang minim sudah bisa memperoleh pengetahuan yang tidak sebanding dengan anggaran dana jika dilakukan dengan tatap muka secara langsung. Seiring aktivitas tersebut dalam pandangan sebagian orang tidak bisa persamakan persepsinya, muncul sikap kontra terhadap kehadiran internet. Internet merupakan alat untuk pembodohan massal yang secara sistematis meracuni pikiran seseorang sehingga terjadi penurunan kecerdasan. Untuk mengantisipasi dan meminimailisir terjadinya persepsi tersebut, maka Islam berusaha menawarkan solusi bagaimana pemakaian internet yang bermanfaat. Tujuan kajian ini untuk mengetahui peran pendidik dalam menerapkan penggunaan internet yang sehat menurut islam.

\section{HASIL KAJIAN dan PEMBAHASAN \\ Cara Islam Mengajarkan Internet Sehat}

Mendidik anak ibarat mendaki gunung yang tinggi, kita tahu puncaknya tapi kita tidak pernah tahu kapan sampai di puncak itu. Setiap keluarga menginginkan anak yang shaleh, itulah puncak dari pendidikan anak. Untuk mencapai tujuan anak shaleh tidaklah mudah, berbagai rintangan datang menyapa. Tidak cukup hanya sekedar membaca puluhan buku pendidikan yang ditulis oleh pakar pendidikan anak, tidak cukup pula 
mengikuti berbagai forum yang mengkaji pendidikan anak. Namun, jika segudang tips tidak diterapkan akan banyak kendala yang ditemukan karena beda anak beda cara penanganan, beda suasana berbeda juga kiat yang harus diterapkan. Tidak ubahnya juga dengan kiat mengantisipasi penggunaan internet agar putra-putri sebagai anak bangsa tidak terperosok dalam penyimpangan moral. Maka wajar jika dalam Al-Quran sudah Allah katakan di dalam Q.S. At-Tahrim ayat 6; "Hai orang-orang yang beriman, peliharalah dirimu dan keluargamu dari api neraka yang bahan bakarnya adalah manusia dan batu. Penjaganya Malaikat-malaikat yang kasar, keras dan tidak mendurhakai Allah SWT terhadap apa yang diperintahkan_Nya kepada mereka dan selalu mengerjakan apa yang diperintahkan".

Dari ayat tersebut beberapa ulama memberikan penafsiran yang beragam tentang "peliharalah dirimu dan keluargamu dari api neraka". Sufyan As-Sauri menafsirkan makna yang dimaksud dalam perintah tersebut adalah didiklah mereka dan ajarilah mereka. Ali Ibnu Thalhah telah meriwayatkan dari Ibnu Abbas sehubungan dengan makna "peliharalah" adalah amalkanlah ketaatan kepada Allah SWT dan hindarilah perbuatan-perbuatan durhaka kepada Allah SWT, serta perintahkanlah keluarganya berdzikir dan mengingat, niscaya Allah SWT akan menyelamatkanmu dari siksa api neraka.

Pendapat lain yang bermakna sama dalam bentuk antisipasi terhadap anggota keluarga sendiri adalah dari Qatadah mengatakan bahwa selaku pendidik - guru dan orang tua - harus memerintahkan anak-anak mereka untuk taat kepada Allah SWT dan mencegah mereka dari perbuatan durhaka kepada Allah SWT, selain itu juga perlunya penegakkan aturan disiplin untuk mengerjakan perintah Allah dan membantu anak dalam mengamalkan ibadah. Apabila pendidik melihat dari kalangan mereka melakukan perbuatan maksiat langkah yang segera diambil adalah mencegah dan melarangnya. Seiring dengan ayat tersebut, Allah juga melarang keras setiap individu melakukan perbuatan yang membinasakan diri, dalam kata lain merusak dan menganiaya diri baik terhadap fisik, pikiran maupun jiwa. Larangan ini terdapat dalam Q.S Al-Baqarah/ 2: 195; 


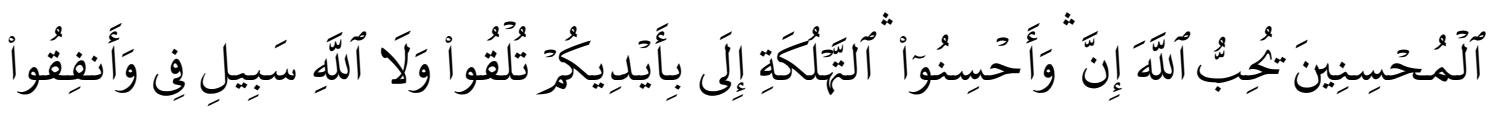

Artinya :

"Dan belanjakanlah (harta bendamu) di jalan Allah, dan janganlah kamu menjatuhkan dirimu sendiri ke dalam kebinasaan, dan berbuat baiklah, Karena Sesungguhnya Allah menyukai orang-orang yang berbuat baik" (QS. Al-Baqarah [2]:195)

Guru adalah induk segala profesi. Apa pun jabatan profesi yang kita miliki, semuanya tidak terlepas dari jasa guru. Guru adalah pelukis masa depan. Guru adalah arsitek peradaban. Lalu guru manakah yang patut mendapat penghormatan dan kemuliaan itu? Tentu, mereka adalah guru sejati. Itulah guru yang beriman, cerdas, berkarakter dan berhati mulia. Mereka tampil sebagai guru profesional, jadi teladan, memberi inspirasi, mencerdaskan dan mencerahkan serta mengantarkan peserta didiknya menjadi hamba yang mengenal khaliqnya. Guru sejati tak boleh sakit, terlebih sakit ruhani. Dendam, dengki, pemarah, pengadu domba, atau tamak akan harta dan kemewahan dunia harus dijauhi guru. Sebab guru menjadi orang yang digugu dan ditiru.

Namun guru bukan malaikat. Adakalanya mereka salah dan khilaf. Tetapi guru yang ideal mengetahui jika ia memiliki kesalahan sehingga ia tidak larut dalam kesalahannya. Jika kesalahan itu tetap berulang, ia cepat sadar sedang mengidap penyakit hati, lalu ia segera mengobatinya. Itulah kearifan seorang guru. Guru juga manusia biasa. Karena itu, guru juga memiliki kebutuhan fisik. Mereka perlu makan dan kehidupan yang layak. Mereka berhak memperoleh kesejahteraan yang dapat menjamin kesehatan dan pendidikan anak-anaknya Terlepas dari berbagai persoalan itu, guru mesti tetap semangat. Guru tidak boleh pesimis. Guru adalah benteng terakhir mewujudkan manusia paripurna (insan kamil). Profesi guru adalah pilihan.Maka lakukan tugas guru dengan sepenuh jiwa. Bukankah di saat memilih tugas sebagai guru, kita telah menerima amanah dari orang tua untuk mendidik anak-anak mereka? Dan mengemban amanah merupakan suatu kewajiban. Maka jadilah guru sejati.

Caranya? Belajarlah pada Sang Guru Utama, Nabi Muhammad SAW. Peran dan tugas Rasulullah SAW sebagai guru sejati dapat dilihat dari firman Allah SWT: 
sebagaimana (kami telah menyempurnakan nikmat Kami kepadamu) Kami telah mengutus kepadamu Rasul di antara kamu yang membacakan ayat-ayat Kami kepada kamu dan mensucikan kamu dan mengajarkan kepadamu Al kitab dan Al-Hikmah, serta mengajarkan kepada kamu apa yang belum kamu ketahui (QS. Al-baqarah [2]: 151).

Paling tidak ada lima tugas Nabi SAW sebagai guru sejati yang seharusnya dipedomani dan dikembangkan oleh guru hari ini. Pertama, tilawah, yaitu mengajar dengan membacakan ayat-ayat Allah. Membaca ayat-ayat Allah, baik yang tertulis dalam Alquran maupun dengan mengamati fenomena alam sebagai ayat-Nya penting dilakukan sehingga memiliki keyakinan bahwa semua ciptaan Allah memiliki keteraturan yang bersumber dari Allah serta memandang tak satu pun ciptaan-Nya yang sia-sia. Hal ini relevan dengan kebijakan pemerintah dewasa ini dengan "Gerakan Literasi Sekolah”. Guru dituntut untuk menjadi sosok literal dan mampu memotivasi peserta didik untuk gemar membaca. Meski guru menjadi sumber belajar, tetapi guru tak boleh berhenti membaca, menelaah, dan melakukan penelitian sederhana sehingga dalam menjalankan tugas ia tampil profesional. Aktivitas membaca harus didasari oleh tauhid, seperti yang tersirat dalam wahyu pertama diterima Nabi SAW:Bacalah dengan menyebut nama Tuhanmu yang menciptakan. Dalam konteks ini, guru harus membaca agar semakin dekat dengan Sang Pencipta.

Kedua, tazkiyah, yaitu menyucikan. Rasulullah SAW telah berhasil menyucikan jiwa umatnya dari segala bentuk kemusyrikan, kekafiran dan kemunafikan. Hal ini bisa dilakukan karena Nabi SAW sendiri memiliki jiwa yang bersih, akhlak yang mulia (QS. Qalam ayat 4). Dalam konteks ini, guru harus berupaya senantiasa menyucikan jiwanya. Sebab, guru yang berjiwa kotor tidak akan mampu menyucikan jiwa peserta didiknya. Inilah kunci pembentukan karakter yang kini lagi dikembangkan oleh pemerintahan Jokowi-JK. Penguatan Pendidikan Karakter (PPK) pasti gagal jika guru hadir tanpa karakter. Sebaliknya, PPK niscaya berhasil di tangan guru yang memiliki kebeningan hati, jiwa yang suci dan perilaku yang berbudi.

Ketiga, ta'lim al-kitab, yaitu mengajarkan kitab, Alquran. Inilah mukjizat terbesar Nabi SAW. Dengan Alquran, Allah menuntun manusia untuk memperoleh hidayah-Nya sehingga benih-benih kasih sayang tumbuh mekar dalam dada setiap mukmin. Umat pun tampil membawa rahmat bagi segenap alam. Guru sejati juga bertugas mengajarkan pesan Alquran kepada peserta didiknya. Apa pun mata pelajaran 
yang diampu oleh guru, hendaklah diintegrasikan dengan ayat-ayat Allah SWT. Hal ini relevan dengan kurikulum 2013 yang memperhatikan sikap spiritual pada Kompetensi Inti satu (KI 1). Sikap spiritual peserta didik akan mudah terbentuk melalui pendidikan agama. Sementara dasar utama ajaran agama Islam adalah Alquran. Maka ilmu yang diajarkan oleh setiap guru hendaknya terkait dengan pesan-pesan mulia Alquran. Dalam hal ini, guru yang beragama Islam dapat bekerja sama dengan guru PAI untuk merumuskan pola pembelajaran terintegrasi dengan ayat-ayat atau pesan-pesan Alquran. Begitu pula gerakan literasi di sekolah dapat dikembangkan dengan melakukan kajian terhadap ayat-ayat Alquran, sebab negeri ini akan berjaya jika rakyatnya dekat dengan kitab sucinya.

Keempat, ta'lim al-hikmah, yaitu mengajarkan hikmah. Dalam tafsir Ibn Katsir, hikmah berarti Sunnah. Rasulullah SAW mengajar manusia dengan ucapan dan tindakannya yang sesuai dengan Alquran. Itulah hadis yang juga menjadi pegangan hidup manusia. Sementara Imam Nawawi al-Bantani berpendapat bahwa hikmah adalah kecocokan perbuatan dengan ilmu, maka siapa yang serasi antara perbuatan dengan ilmunya, berarti ia telah mendapat hikmah. Guru sejati juga mengajar peserta didiknya dengan hikmah. Ini bermakna bahwa guru harus meneladani perilaku Nabi SAW dengan mempedomani sunnahnya. Guru juga mesti memiliki integritas kepribadian; satu antara perkataan, pemikiran dan perbuatan. Perilaku guru harus selaras dengan keilmuan yang dimilikinya. Jadilah guru teladan sehingga peserta didik memiliki panutan dalam memperoleh hikmah. Dalam surat QS. al-Baqarah [2]: 269 dijelaskan bahwa hikmah diberikan Allah kepada siapa saja yang dikehendaki-Nya. Mereka termasuk dalam kategori ulul albab. Adapun karakter ulul albab adalah mereka yang senantiasa berzikir dan berpikir (QS. Ali Imran [3]: 190-191). Maka di antara upaya guru mendidik peserta didiknya dengan hikmah adalah dengan melatih zikir dan pikir.

Kelima, ta'lim maa lam takunu ta'lamun, yaitu mengajarkan apa-apa yang belum kamu ketahui. Nabi SAW adalah pendidik sejati yang mengajarkan berbagai ilmu pengetahuan kepada umatnya berdasarkan tuntunan wahyu yang ia terima. Sebelumnya masyarakat jahiliyah tenggelam dalam kedunguan akidah, tertutupnya hati nurani dan menjadi pemuja kemewahan dunia. Lalu Nabi SAW mendidik manusia untuk mengetahui hakikat diri dan pencipta-Nya. Umat manusia pun mengenal Allah dan memahami cara mengabdikan diri pada-Nya. Guru sejati penuh dengan kreasi dan 
inovasi. Ia dapat mengajarkan sesuatu yang benar-benar asing, belum diketahui oleh peserta didiknya. Hal ini memicu inovasi, penemuan-penemuan produk teknologi, atau konsep-konsep baru yang bermanfaat, mempermudah dan membantu kehidupan manusia sehari-hari.

Lima peran dan tugas Rasulullah SAW sebagai guru sejati dalam QS. AlBaqarah ayat 151 di atas menjadi pelajaran berharga bagi guru Indonesia. Keteladanan Nabi SAW sebagai pendidik tidak hanya menjadi contoh bagi guru muslim semata, tetapi bagi seluruh guru Indonesia. Sebab Nabi SAW menginspirasi dunia untuk membangun peradaban bernilai tinggi, seperti masyarakat madani yang memancarkan cahaya kedamaian dan kebahagiaan (madinah al-munawwarah) (Kosim, 2011).

Selain ke-lima peran dan tugas Rasulullah SAW di atas sebagai seorang pendidik juga harus melek teknologi sehingga dapat mengajarkan cara yang benar kepada siswanya. Berikut ini beberapa langkah yang dapat di lakukan oleh pengasuh, baik guru maupun orang tua;

1. Melakukan pendampingan

Pendampingan dalam hal ini adalah pengawasan secara edukatif terhadap anak kita yang telah mengetahui wawasan internet, baik berasal dari Handphone maupun Komputer. Pendampingan terhadap anak dapat dilakukan dengan cara;

a. Memberikan anak waktu untuk membuka internet dengan menentukan waktunya, misalkan 1 jam.

b. Waktu yang telah diberikan kepada anak hendaknya menjadi momen berharga bagi para orang tua untuk memberikan edukasi dengan cara memandu dan menemani anak, sehingga hal-hal yang baru diketahui anak bisa langsung di tanyakan kepada orang tua, dan mereka para orang tua harus menjelaskan dengan tepat. Jika situs terlarang, maka kita sampaikan kepada anak bahwa situs ini tidaklah baik untuk di lihat karena dapat merusak pikiran serta mendatangkan dosa. Namun, para orang tua juga perlu menjelaskan tentang pentingnya organorgan tubuh kita yang harus di jaga seperti aurat, karena melihat aurat orang lain adalah hal yang di larang oleh agama. Orang tua hendaknya tidak menunjukan sikap marah seketika, namun memberikan teguran dengan cara yang edukatif.

c. Orang tua dapat meletakkan komputer di ruang pertemuan/ ruang umum sehingga apapun yang sedang dilakukan anak dapat terawasi dengan baik. 
d. Hendaknya orang tua tidak membiarkan anak bermain internet sendiri di dalam kamar, agar tertutup peluang bagi anak membuka situs-situs yang dilarang.

e. Orang tua dapat mengecek histori pada geogle. Hal ini untuk melihat situs-situs yang sering di buka oleh anak, hingga situs terakhir yang baru saja di bukanya.

f. Orang tua dapat memberikan kepercayaan kepada anak saat mereka pergi bekerja dengan cara menanamkan sifat-sifat Allah, bahwa Allah Maha Melihat. Allah juga mengutus Malaikat yang selalu mengawasi perbuatan kita dan mencatat segala aktivitas baik dan buruk manusia, sekalipun tidak dalam pengawasan orang tua.

2. Gerakan 1821

Gerakan 1821 adalah himbauan kepada para pendidik dan orang tua untuk melakukan puasa gadget selama 3 jam, yaitu mulai pukul $18.00 \mathrm{~s} / \mathrm{d} 21.00$ malam. Selama 3 jam para orang tua dianjurkan melakukan 3B, yaitu Bermain, Belajar dan Berdo'a. Rasulullah SAW dalam mendidik keluarganya tidak terlepas dari 3 kegiatan tersebut. Rasulullah SAW tidak pernah bercanda secara berlebihan, dalam gurauan beliau tidak luput dari penanaman nilai-nilai Islam disertai do'a-do'a harian yang di ajarkan. Dalam konteks ini, perlu dicontoh bagi para pendidik dan orang tua untuk meluangkan waktu bersama buah hati tercinta guna melakukan hal-hal yang bermanfaat. Sebagai contoh mendampingi anak mengerjakan PR, bercerita kisahkisah penting keluarga, tentang pahlawan Islam, pahlawan Indonesia dan sebagainya.

3. Memblokir Situs Porno

Pencegahan peredaran situs porno dapat dikendalikan dan diminimalisir melalui aplikasi yang terpasang pada HP Android, dikhawatirkan secara tidak sengaja terbuka oleh anak. Maka, langkah pembatasan tersebut dapat dilakukan dengan cara:

a. Buka Youtube

b. Pilih tanda/gambar di pojok kanan atas

c. Pilih : setting/ setelan, kemudian pilih general/ umum

d. Pilih restricted mode/ mode terbatas. Menu ini akan memfilter video-video yang memiliki konten tidak layak bagi anak maupun dewasa.

e. Pada bagian chat juga dapat dilakukan dengan cara, "Tahan chat yang mengandung unsur tertentu". 


\section{f. Selesai}

Selain Youtube, sebaiknya juga dilakukan filter pada aplikasi "play store" Android, agar anak tidak menginstal aplikasi/ game yang tidak baik sesuai umurnya. Caranya adalah:

a. Pilih menu settings di play store

b. Pilih menu "Parental Controls"

c. Kemudian geser tombol "On" ke posisi kanan

d. Masukkan "Pin" control oleh orang tua agar anak tidak mengetahuinya.

e. "set content restrictions for this device" dan tentukan umur yang sesuai dengan pengguna.

Berdasarkan langkah di atas, setidaknya selaku orang tua dan pendidik telah melakukan apa yang di perintahkan oleh Allah dan Rasul-Nya, sehingga anak kita dapat menerapkan penggunaan internet sehat menurut Islam.

\section{SIMPULAN DAN SARAN}

Penulis menyimpulkan bahwa langkah preventif yang dapat dilakukan pendidik dan orang tua agar anak didik dapat menerapkan penggunaan internet yang sehat menurut Islam adalah dengan cara mengikuti Peran dan tugas Rasulullah SAW dalam mendidik, serta melakukan beberapa trik preventif seperti melakukan pendampingan, melakukan gerakan 1821, dan melakukan pengawasan edukatif terhadap penggunaan internet anak. Kajian ilmiah ini tidak terlepas dari kekurangan, maka dari itu diharapkan kepada pembaca agar dapat memberikan masukan yang bersifat konstruktif. 


\section{DAFTAR PUSTAKA}

Budiman, A. (2017). Berita Bohong (Hoax) Di Media Sosial Dan Pembentukan Opini Publik. Majalah Info Singkat Pemerintahan Dalam Negeri Isu Aktual, 9.

Halim, N. A. (2015). Penggunaan Media Internet di Kalangan Remaja Untuk Mengembangkan Pemahaman Keislaman. Jurnal RISALAH, 26(3), 132-150.

Hanifah, I. R. U. (2013). Kejahatan Pornografi: Upaya Pencegahan dan Penanggulangannya di Kabupaten Ponorogo. Justitia Islamica, 10(2).

Hassan, J., \& Rashid, R. S. R. A. (2012). Ketagihan Penggunaan Internet Di Kalangan Remaja Sekolah Tingkatan 4 Di Bandaraya Johor Bahru. Journal of Technical, Vocational \& Engineering Education, 6, 23-43.

Ihsan, M. (2016). Pengaruh Terpaan Media Internet dan Pola Pergaulan Terhadap Karakter Peserta Didik. Tsamrah Al-Fikri, 10, 103-120.

Iman, N., Katni, \& Kurniawan, E. (2014). Internet Sehat Bagi Santri. MUADDIB, 4(2), $38-52$.

Ismail, M. (2014). Studi Korelasi Implementasi Fiqh Parenting Terhadap Pola Internet Sehat Dalam Pendidikan Anak, 9(1).

Kosim, M. (2011). Urgensi Pendidikan Karakter. Karsa.

Kurniali, S. (2011). Peran Media Sosial Di Internet Pada Penerapan Proses Knowledge Management. ComTech, 2(1), 167-174.

R, M. H., Mudjiran, \& Syukur, Y. (2012). Dampak Pornografi Terhadap Perilaku Siswa dan Upaya Guru Pembimbing Untuk Mengatasinya. Konselor, 1(1), 1-8.

Rumtianing, I., \& Hanifah, U. (2013). Kejahatan pornografi: Upaya Pencegahan dan Penanggulangannya di Kabupaten Ponorogo. Justitia Islamica.

Satya, B., Rosidi, A., \& Arief, M. R. (2012). Merancang Framework Policy Internet Sehat Perguruan Tinggi. Jurnal Telematika, 5(2), 49-59.

Setiawan, A. B. (2011). Penanggulangan Dampak Negatif Akses Internet di Pondok Pesantren Melalui Program Internet Sehat. Jurnal Penelitian Komunikasi, 14(2), 99-114.

Situmorang, J. R. (2012). Pemanfaatan Internet Sebagai New Media Dalam Bidang Politik , Bisnis , Pendidikan dan Sosial Budaya. Jurnal Administrasi Bisnis, 8(1), 77-91.

Sudiran. (2015). Sikap Guru dan Tingkat Penggunaan Teknologi Informasi dan Komunikasi di Kelas Sebagai Media Pembelajaran Bahasa Inggris di SMA 3 dan SMK 1 Muhammadiyah Kota Batu Sudiran. JINoP (Jurnal Inovasi Pembelajaran), $1(1), 98-112$. 
Supratman, L. P. (2015). Konsep Diri Remaja Dari Keluarga Bercerai. Jurnal Penelitian Komunikasi, 16(2), 129-140.

Suyatno, T. (2011). Pengaruh Pornografi Terhadap Perilaku Belajar Siswa ( Studi Kasus : Sekolah Menengah X ). Jurnal Pendidikan Dompet Dhuafa, 1.

Widiastuti, N., \& Elshap, D. S. (2015). Pola Asuh Orang Tua Sebagai Upaya Menumbuhkan Sikap Tanggung Jawab pada Anak Dalam Menggunakan Teknologi Komunikasi. Jurnal Ilmiah UPT P2M STKIP Siliwangi, 2(2), 148-159.

Wikipedia. (2018). Internet. Retrieved from https://id.wikipedia.org/wiki/Internet

Winarso, D., Syahril, Aryanto, Arribe, E., \& Diansyah, R. (2017). Pemanfaatan Internet Sehat Menuju Kehidupan Berkemajuan. JURNAL Untuk Mu negeRI, 1(1), 19-23.

Wiranto, S. (2014). Penerapan Teknologi Informasi dan Komunikasi Sebagai Media Interaksi Guru-Siswa. Varia Pendidikan, 26(2), 157-166.

Yudhianto-detikInet. (2017). 132 Juta Pengguna Internet Indonesia, 40\% Penggila Medsos. Retrieved from https://inet.detik.com/cyberlife/d-3659956/132-jutapengguna-internet-indonesia-40-penggila-medsos 